\title{
Stream Nutrient Retention in Three Northeastern Oklahoma Agricultural Catchments
}

\author{
B. E. Haggard, D. E. Storm, R. D. Tejral, Y. A. Popova, V. G. Keyworth, E. H. Stanley
}

\begin{abstract}
Stream nutrient retention was examined in three adjacent agricultural catchments (Cherokee Creek, Cloud Creek, and Dry Creek) in the Ozark Plateau. Retention efficiency was measured using short-term nutrient and tracer injections to estimate nutrient uptake length $\left(S_{w}\right)$ during summer 1999 and winter 2000. A one-dimensional transport model was used to estimate dispersion, transient storage size, and exchange. Soluble reactive $P(S R P)$ and $\mathrm{NO}_{3}-\mathrm{N}$ concentrations were least in the stream with the lowest proportion of pasture in the upland (Dry Creek), whereas concentrations and land use were similar in Cherokee Creek and Cloud Creek. Water column SRP concentrations were similar between seasons in all streams, but $\mathrm{NO}_{3}-\mathrm{N}$ concentrations varied significantly. Injected $\mathrm{NO}_{3}-\mathrm{N}$ was not significantly retained in these systems, probably because the streams were saturated by ambient $\mathrm{NO}_{3}-\mathrm{N}$ concentrations (greater than $0.1 \mathrm{mg} L^{-1}$ ). Phosphorus was retained during summer injections ( $S_{w}$ ranged from $200-900 \mathrm{~m}$ ), but $S_{w}$ regressions were not significant in winter. Variation in catchment land use was not a major determinant in P retention during summer, but stream hydrology, such as discharge and transient storage, was a regulating factor. Therefore, land use changes that alter stream hydrology may have a greater impact on $P$ retention in these streams.
\end{abstract}

Keywords. Aquatic ecology, Water quality, Nutrient retention, Ozark streams, Oklahoma.

I n the last 25 years, non-point source (NPS) pollution has become a substantial problem and has been identified as the cause of anthropogenic eutrophication in lakes, Creservoirs, rivers, and streams (Carpenter et al., 1998). Non-point sources are spatially and temporally variable; however, it is clear that agricultural land use is a major contributor to nutrient loading from diffuse sources (Sharpley et al., 1994; Carpenter et al., 1998). In northeastern Oklahoma, the issue of NPS nutrient loading has become a major concern of the state environmental agencies due to the rapid growth of confined animal operations, particularly poultry and swine industries.

Evidence exists which shows that high levels of agricultural land use in catchments are associated with increased nutrient loading to streams (Newman, 1996; Vitousek et al., 1997; Daniel et al., 1998). How does this increased diffuse nutrient loading affect in-stream nutrient processes? Investigating possible effects of changes in

Article was submitted for review in July 2000; approved for publication by the Soil \& Water Division of ASAE in February 2001. Presented at the 2000 ASAE Annual Meeting as Paper No. 00-2120.

The authors are Brian E. Haggard, ASAE Member, Hydrologist/Soil Scientist, USDA Agricultural Research Service, University of Arkansas, Fayetteville, Arkansas; Daniel E. Storm, ASAE Member, Associate Professor, Ronald D. Tejral, Research Engineer, and Yulia A. Popova and Valerie G. Keyworth, Graduate Research Assistants, Department of Biosystems and Agricultural Engineering, Oklahoma State University, Stillwater, Oklahoma; and Emily H. Stanley, Assistant Professor, Center for Limnology, University of Wisconsin, Madison, Wisconsin. Corresponding author: Brian Haggard, USDA-ARS, 203 Engineering Hall, University of Arkansas, Fayetteville, AR 72701; phone: 501-575-2879; fax: 501-575-2846; e-mail: haggard@uark.edu. catchment land use on stream nutrient retention is essential for downstream water quality management. While in-stream processes are not significant buffers of annual nutrient fluxes (Meyer and Likens, 1979), differences in seasonal nutrient retention in streams influence the timing, magnitude, and form of nutrients transported downstream (Meyer et al., 1988) and thus can impact watershed management strategies and goals.

Nutrient cycling in streams involves longitudinal displacement of a nutrient molecule during a cycle and has been described as "spiraling" (Newbold et al., 1981; Webster and Patten, 1979). The length required to complete one spiral, or the spiraling length, is composed of two parts: uptake length $\left(\mathrm{S}_{\mathrm{w}}\right)$ and turnover length $\left(\mathrm{S}_{\mathrm{p}}\right)$ (Stream Solute Workshop, 1990). $S_{W}$ is the average distance a nutrient molecule travels in the water column before removal, and $S_{p}$ is the distance required for a nutrient molecule to be regenerated or released from the particulate form (Newbold, 1992). $S_{p}$ requires the use of isotopes for calculation (e.g., see Newbold et al., 1981, 1983; Mulholland et al., 1985), whereas $\mathrm{S}_{\mathrm{w}}$ can be estimated by stable nutrient additions (Mulholland et al., 1990; Stream Solute Workshop, 1990; Webster and Ehrman, 1996).

As the nutrient molecule travels downstream, it may cycle from the dissolved inorganic form to the particulate form and back into the dissolved inorganic form many times, and the number of cycles that occur in a given reach depends upon the spiraling length. Spiraling length is a measure of the nutrient retention efficiency of the stream, that is, the degree to which nutrient transport is inhibited compared to conservative solutes (Martí and Sabater, 1996). $\mathrm{S}_{\mathrm{w}}$ generally constitutes greater than $90 \%$ of the spiraling length (Newbold et al., 
1983; Mulholland et al., 1985), and has been described as an index of stream utilization of nutrients supplied by the terrestrial ecosystem (Newbold et al., 1981).

In the last decade, $S_{\mathrm{W}}$ has been widely used to assess nutrient retention in streams. Several studies have shown spatial variation in $\mathrm{S}_{\mathrm{W}}$ within and among streams (Aumen et al., 1990; D'Angelo and Webster, 1991; Martí and Sabater, 1996; Munn and Meyer, 1990), and others have examined temporal variation in $\mathrm{S}_{\mathrm{W}}$ (Martí and Sabater, 1996; Mulholland et al., 1985; Webster et al., 1991). Spatial variation may result from differences in channel form, local environmental conditions, watershed land use, and physiographic features, whereas temporal variation is largely related to temperature, hydrology, and allochthonous inputs into the stream ecosystem.

In this study, spatial and seasonal variations in nutrient retention during summer and winter were examined in three streams draining adjacent agricultural catchments in northeastern Oklahoma. These seasons were selected because warmer temperatures are associated with increased biotic activity, and winter is the dormant season. Our objectives were: (1) to compare stream soluble reactive $\mathrm{P}$ $(\mathrm{SRP})$ and nitrate $\left(\mathrm{NO}_{3}-\mathrm{N}\right)$ retention in summer and winter, (2) to compare ammonium $\left(\mathrm{NH}_{4}-\mathrm{N}\right)$ and $\mathrm{NO}_{3}-\mathrm{N}$ retention, and (3) to evaluate the importance of hydrologic properties and catchment land use on nutrient retention.

\section{Study Site Descriptions}

The Lake Eucha-Spavinaw Basin has been identified as a nutrient-limited watershed (NLW) and is one of several high-priority basins within Oklahoma. It is in the Ozark Plateau in northeastern Oklahoma and northwest Arkansas (fig. 1). Identification of this basin as an NLW results in actions being taken to control nutrients entering the reservoirs. Lake Eucha was constructed in the 1950s to provide a constant source of water to Lake Spavinaw several kilometers downstream on Spavinaw Creek. This impoundment series serves as a municipal water supply to the city of Tulsa, Oklahoma, and surrounding rural communities. Lake Eucha has experienced substantial increases in nutrient concentrations over the last 25 years (Oklahoma Conservation Commission, 1997). Furthermore, taste and odor problems and the cost of water treatment chemicals have increased significantly (Slaughter, 2000, personal communication).

Three streams within the Lake Eucha-Spavinaw Basin were selected to conduct short-term nutrient injections to estimate nutrient uptake length. Dry Creek, Cloud Creek, and Cherokee Creek are in adjacent catchments. Dry Creek drains directly into Lake Eucha, and Cloud Creek and Cherokee Creek drain into Spavinaw Creek upstream of the riverine zone of Lake Eucha (fig. 1). These streams were selected because the proportion of agricultural land use varied from extensive confined animal operations and high percent pasture in Cloud Creek and Cherokee Creek to fewer confined animal operations and lower percent pasture in Dry Creek (table 1). A study reach approximately $200 \mathrm{~m}$ long was selected in 3rd or 4th order sections of each stream (stream order was determined using 1:24000 United States Geological Survey topography maps and includes perennial and intermittent streams). Stream substrate was cobble with only a small fraction of fine sediments. All sites had large gravel beds lateral to the stream channel. Riparian zones were dominated by sycamore trees in Dry Creek and a mix of sycamore trees and other hardwoods in Cloud Creek and Cherokee Creek. The riparian zone vegetation did not appear to substantially reduce insolation in these systems. Dry Creek and Cherokee Creek had large cool season grass pastures on either side of the stream up-slope of the riparian zone, whereas the up-slope vegetation at Cloud Creek was characterized by underbrush and forest layers. The dominant soils in the riparian and upland terrestrial ecosystems are shallow silt loams. The reaches selected in Dry Creek and

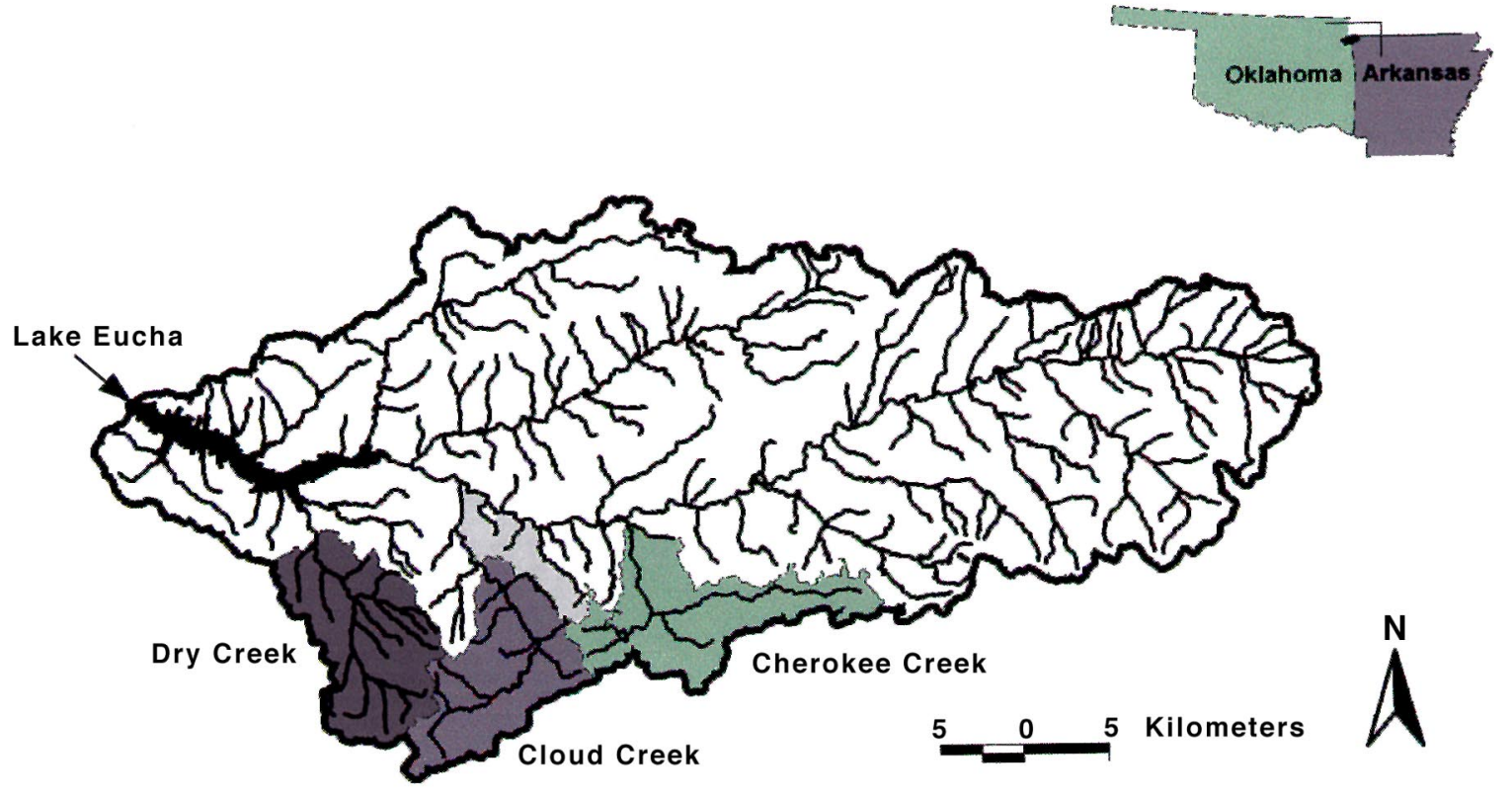

Figure 1. Lake Eucha Basin and Cherokee Creek, Cloud Creek, and Dry Creek catchments. 
Table 1. Global positioning system coordinates, catchment land use, and stream order for the three northeastern Oklahoma streams.

\begin{tabular}{|c|c|c|c|c|c|c|c|}
\hline \multirow[b]{2}{*}{ Catchment } & \multirow{2}{*}{$\begin{array}{l}\text { Latitude }^{[\mathrm{a}]} \\
\left(^{\circ}\right)\end{array}$} & \multirow{2}{*}{$\begin{array}{c}\text { Longitude }{ }^{[\mathrm{a}]} \\
\left({ }^{\circ}\right)\end{array}$} & \multirow{2}{*}{$\begin{array}{l}\text { Area } \\
\left(\mathrm{km}^{2}\right)\end{array}$} & \multicolumn{3}{|c|}{$\%$ Land Use ${ }^{[\mathrm{b}]}$} & \multirow{2}{*}{$\begin{array}{l}\text { Stream } \\
\text { Order }\end{array}$} \\
\hline & & & & Past & For & Urb & \\
\hline Cherokee & $36.19 .16 \mathrm{~N}$ & 94.39.57 W & 50 & 66 & 32 & 2 & $3 \mathrm{rd}$ \\
\hline Cloud & $36.18 .20 \mathrm{~N}$ & $94.44 .40 \mathrm{~W}$ & 47 & 63 & 36 & 1 & $3 r d$ \\
\hline Dry & $36.18 .56 \mathrm{~N}$ & $94.50 .02 \mathrm{~W}$ & 51 & 24 & 76 & $<1$ & 4 th \\
\hline
\end{tabular}

[a] Denotes location of experimental study reach for each stream.

[b] "Past" denotes land use in pasture and other agricultural practices $(<2 \%$ cropland in any of the three catchments), "For" denotes land use in forest and woodland, and "Urb" denotes land use in urban-suburban.

Cherokee Creek were also long-term water quality monitoring sites for the city of Tulsa, and the Cloud Creek reach was approximately $1 \mathrm{~km}$ upstream of a similar long-term monitoring site.

\section{MeThodS}

\section{NUTRIENT AND Tracer INJECTIONS}

Short-term nutrient additions were performed in the summer of 1999 and in the following winter. Summer injections were conducted on 19 and 27 July and on 3 and 19 August 1999, and winter injections were conducted on 6,14, and 21 January 2000. On all sampling dates, nutrients and a hydrologic tracer were injected into the stream using a peristaltic pump, which delivered a solution enriched with $\mathrm{PO}_{4}-\mathrm{P}, \mathrm{NO}_{3}-\mathrm{N}$, and $\mathrm{Cl}^{-}$ions to eight pressure-compensating emitters through clear polyvinyl plastic tubing (fig. 2). On 6 January 2000, $\mathrm{NH}_{4}-\mathrm{N}$ was also used in the injection solution. Emitters varied in their discharge rate from 4 to $15 \mathrm{~L}$ $\mathrm{h}^{-1}$, depending on stream flow and the level of nutrient enrichment desired in the stream. The injection apparatus was placed just upstream of a riffle during the short-term additions to induce complete mixing of the injection solution and stream water. Background water samples were collected prior to the injection at five sampling stations along the study reach in each stream. The nutrient solution was then released into the stream at a constant rate until conductivity

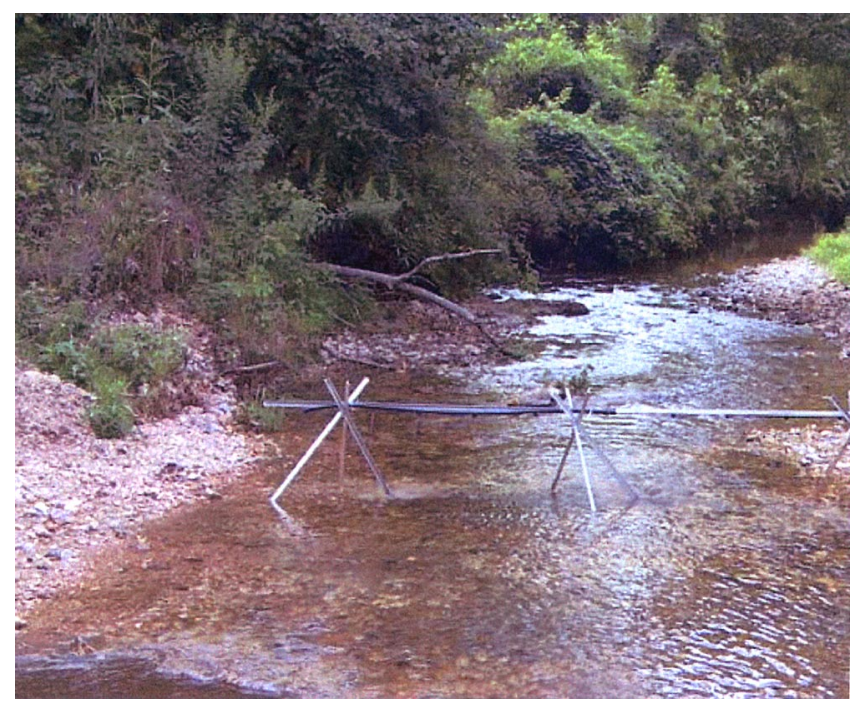

Figure 2. Photograph of the injection apparatus in Cloud Creek during an injection pilot run. measurements at the most downstream station stabilized, and injections lasted less than $2 \mathrm{~h}$. The stabilization of the conservative tracer $\left(\mathrm{Cl}^{-}\right)$, characterized by a plateau of water column conductivity values, indicated that the stream water and the injected solutes were in equilibrium. Plateau water samples were taken at each of the five sampling stations approximately $10-15 \mathrm{~min}$ after equilibrium was reached at the most downstream site. Conductivity (Model 30, YSI Inc., Yellow Springs, Ohio) was recorded from the time the injection began until conductivity returned to near-background levels after the injection ended.

Water samples were collected at the most downstream sampling station, then at the station immediately upstream, and continued to the most upstream station throughout the study reach. This technique was used to avoid influencing nutrient and tracer concentrations by disturbing the stream benthos, and collection of all samples was accomplished in less than $10 \mathrm{~min}$. Both background and plateau water samples were collected in this manner. Three water samples were taken along a transect perpendicular to stream flow at equal intervals with $60 \mathrm{~mL}$ polyethylene syringes and filtered immediately (GF/F glassfiber filters, Whatman, Inc., Clifton, New Jersey) at each station. Filtered water samples were acidified to $\mathrm{pH} 2$ and stored on ice and in the dark until return to the laboratory. Temperature (Model 30, YSI Inc., Yellow Springs, Ohio) and $\mathrm{pH}$ (pH Testr2, Oakton Instruments, Vernon Hills, Illinois) were measured prior to the injection and at plateau conditions at the most downstream sampling point.

\section{LABORATORY Methods}

Upon return to the laboratory, samples were allowed to adjust to room temperature before nutrient and tracer analyses were conducted on a QuikChem 9000 (Lachat Instruments, Milwaukee, Wisconsin). $\mathrm{NO}_{3}-\mathrm{N}$ was determined using cadmium-copper reduction (QuikChem Method 10-107-04-1-A), and $\mathrm{NH}_{4}-\mathrm{N}$ was determined by the alkaline phenol, sodium hypochlorite, and nitroprusside reaction (QuikChem Method 10-107-06-1-B). Chloride was analyzed using mercuric thiocyanate (QuikChem Method 10-117-07-1-C). SRP was determined by the ascorbic acid method (Murphy and Riley, 1962).

\section{Determination of Nutrient AND Hydrologic Parameters}

Nutrients typically exhibit an exponential decline in concentration during short-term addition experiments, and the concentration remaining in the water column is proportional to uptake by the stream benthos (Newbold, 1992). Nutrient concentrations were corrected for background levels at each site and then for losses due to dilution using $\mathrm{Cl}^{-}$data (e.g., see Martí and Sabater, 1996). Corrected concentrations at each sampling station $\left(\mathrm{Conc}_{\mathrm{x}}\right)$ were then divided by the corrected concentration at the most upstream sampling station $\left(\mathrm{Conc}_{0}\right)$ below the injection point and regressed against distance downstream (x):

$$
\ln \left(\frac{\text { Conc }_{x}}{\text { Conc }_{0}}\right)=-\mathrm{kx}
$$


The nutrient uptake coefficient $(\mathrm{k})$ was determined as the slope of the line of the proportion of nutrients remaining in the water versus distance downstream. $S_{W}$ for each injection was then calculated as:

$$
\mathrm{S}_{\mathrm{w}}=-\frac{1}{\mathrm{k}}
$$

Linear uptake rate of ambient nutrients can be calculated using the following equation:

$$
\mathrm{U}=\frac{\text { Conc }_{\mathrm{b}} \times \mathrm{Q}}{\mathrm{S}_{\mathrm{w}}}
$$

where

$\mathrm{U} \quad=$ linear uptake rate $\left(\mathrm{mg} \mathrm{m}^{-1} \mathrm{~s}^{-1}\right)$

Conc $_{\mathrm{b}}=$ background nutrient concentration $\left(\mathrm{mg} \mathrm{L}^{-1}\right)$

$\mathrm{Q} \quad=$ stream discharge $\left(\mathrm{L} \mathrm{s}^{-1}\right)($ e.g., see Stream Solute Workshop, 1990).

Linear uptake can also be normalized for differences in the streambed area by including average width of the stream in the denominator.

To assess hydrological differences among sites and dates, we used OTIS (One-dimensional Transport with Inflow and Storage), a one-dimensional solute transport model (Runkel, 1998), to simulate conservative solute transport $\left(\mathrm{Cl}^{-}\right)$in these streams (see examples in Haggard, 2000). The governing equation of this model is the advection-dispersion equation with a first-order exchange process to account for the influence of transient storage on solute transport (see also Hart, 1995; Stream Solute Workshop, 1990). Conceptually, this process is visualized as downstream movement of water in the channel, plus some portion of the water moving into and out of a transient storage area (fig. 3). Movement of water into the transient storage area slows its downstream movement, and the importance of this transient storage is a function of the advective water velocity, the size of the storage area, and the rate of water exchange between the transient storage area and the main stream channel.

To simplify the model inputs, conductivity measurements were converted to $\mathrm{mg} \mathrm{L}^{-1} \mathrm{Cl}^{-}$using a linear regression of conductivity versus $\mathrm{Cl}^{-}$from background and plateau samples (Martí and Sabater, 1996), and these converted $\mathrm{Cl}^{-}$ values were used in the one-dimensional solute transport model. Temporal changes in $\mathrm{Cl}^{-}$concentration at the most downstream station was used to estimate the cross-sectional area of the transient storage zone $\left(\mathrm{A}_{\mathrm{S}}\right)$, the transient storage exchange coefficient $(\alpha)$, and dispersion (D). Discharge (Q) was estimated using the conservative solute dilution technique, i.e. a measured concentration of $\mathrm{Cl}^{-}$was injected into the stream at a measured rate, discharge was calculated by the difference in observed concentrations, and median travel time was estimated as the time required to achieve half of the plateau conductivity (after Triska et al., 1989). Dispersion, transient storage parameters, and stream cross-sectional area were manually adjusted in OTIS to provide an optimal visual fit between observed and modeled $\mathrm{Cl}^{-}$concentrations. Model parameters were optimized using a using a nonlinear least squares method using a statistical optimization module of OTIS-P (Runkel, 1998).

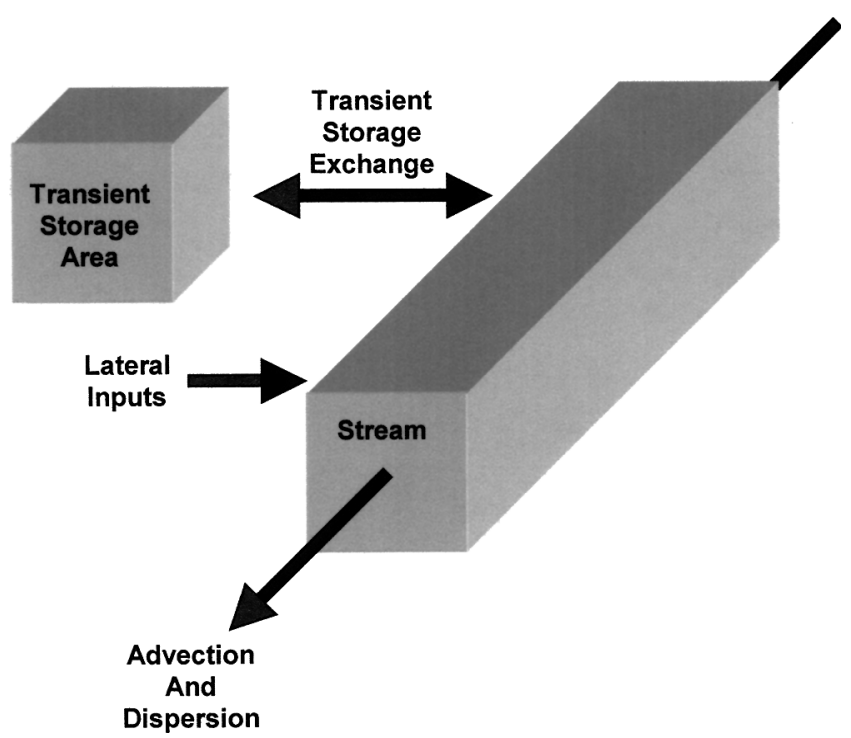

Figure 3. Conceptual model of transient storage and the main channel of the stream.

\section{Results AND Discussion}

\section{Water Chemistry and Nutrient Concentrations}

Baseflow water chemistry showed substantial spatial and temporal variation among the three study streams (table 2). Dry Creek had low baseflow SRP concentrations compared to Cloud Creek and Cherokee Creek (ANOVA on ln-transformed data, Fisher's LSD, $\mathrm{P}<0.05)$ and in comparison with other streams in this basin (City of Tulsa, 2000, unpublished data). $\mathrm{NH}_{4}-\mathrm{N}$ concentrations were generally below detection limits on all sampling dates $\left(<0.030 \mathrm{mg} \mathrm{L}^{-1}\right) . \mathrm{NO}_{3}-\mathrm{N}$ concentrations followed a similar pattern to SRP among the sites, although concentrations in Cherokee Creek were significantly higher than in Cloud Creek, which in turn were higher than Dry Creek (ANOVA on ln-transformed data, Fisher's LSD, $\mathrm{P}<0.05)$. Thus, it appears that both SRP and $\mathrm{NO}_{3}-\mathrm{N}$ concentrations were related to the proportion of land use in pasture in the catchments. This result is not surprising because several investigations have shown a positive relation between stream nutrient concentrations and the proportion of agricultural land use in the catchment (e.g., McFarland and Hauck, 1999; Omernik, 1977; Petersen, 1992), including streams throughout the Ozark Plateau (Petersen et al., 1998) and in particular in streams draining the adjacent Beaver Lake Basin in Arkansas (Haggard, 1997). These high $\mathrm{NO}_{3}-\mathrm{N}$ concentrations are reflective of groundwater enrichment associated with agricultural activities and non-point source pollution in the Ozark Plateau (Petersen et al., 1998).

SRP concentrations were similar between summer and winter in all streams. In contrast, $\mathrm{NO}_{3}-\mathrm{N}$ concentrations were significantly higher in winter compared to summer in Dry Creek and Cloud Creek but decreased significantly in Cherokee Creek during winter (ANOVA on ln-transformed data, Fisher's LSD, $\mathrm{P}<0.05$ ). Seasonal variations in stream $\mathrm{NO}_{3}-\mathrm{N}$ concentrations have been attributed to biotic uptake and denitrification in the riparian zone and the terrestrial ecosystem (Jacobs and Gilliam, 1985; Peterjohn and Correl, 1984). However, in-stream processes may also be a major 
Table 2. Baseflow physicochemical properties, average ambient nutrient concentrations, and SRP uptake length for Cherokee Creek, Cloud Creek, and Dry Creek.

\begin{tabular}{|c|c|c|c|c|c|c|c|}
\hline Date & $\mathrm{pH}$ & $\begin{array}{c}\text { Temperature } \\
\left({ }^{\circ} \mathrm{C}\right)\end{array}$ & $\begin{array}{l}\text { Conductivity } \\
\left(\mathrm{iS} \mathrm{cm}^{-1}\right)\end{array}$ & $\begin{array}{l}\mathrm{NO}_{3}-\mathrm{N} \\
\left(\mathrm{mg} \mathrm{L}^{-1}\right)\end{array}$ & $\begin{array}{c}\mathrm{SRP} \\
\left(\mathrm{mg} \mathrm{L}^{-1}\right)\end{array}$ & $\begin{array}{c}\mathrm{S}_{\mathrm{W}}-\mathrm{SRP}^{[\mathrm{a}]} \\
(\mathrm{m})\end{array}$ & 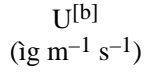 \\
\hline & \multicolumn{7}{|c|}{ Cherokee Creek } \\
\hline 27 July 99 & 7.5 & 20 & 244 & 2.65 & 0.030 & 900 & 4.7 \\
\hline 3 Aug 99 & - & 18 & 242 & 2.66 & 0.028 & 580 & 5.7 \\
\hline 19 Aug 99 & 7.0 & 21 & 266 & - & 0.032 & 200 & 17.9 \\
\hline \multirow[t]{2}{*}{14 Jan 00} & 7.5 & 13 & 287 & 2.32 & 0.028 & $-[\mathrm{c}]$ & - \\
\hline & \multicolumn{7}{|c|}{ Cloud Creek } \\
\hline 19 July 99 & - & 21 & 150 & 1.58 & 0.029 & 339 & 12.2 \\
\hline 27 July 99 & 7.2 & 22 & 158 & 1.54 & 0.032 & 257 & 13.8 \\
\hline 6 Jan 00 & 7.3 & 12 & 164 & 1.93 & 0.032 & - & - \\
\hline \multirow[t]{2}{*}{21 Jan 00} & 7.3 & 11 & 171 & 1.78 & 0.027 & - & - \\
\hline & \multicolumn{7}{|c|}{ Dry Creek } \\
\hline 19 July 99 & - & 19 & 189 & 0.52 & 0.006 & 371 & 2.1 \\
\hline 3 Aug 99 & - & 20 & 209 & 0.60 & 0.012 & 248 & 5.1 \\
\hline 6 Jan 00 & 7.5 & 11 & 223 & 0.94 & 0.011 & - & - \\
\hline 14 Jan 00 & 7.3 & 11 & 224 & 0.85 & 0.010 & - & - \\
\hline
\end{tabular}

[a] $\mathrm{S}_{\mathrm{W}}-\mathrm{SRP}=\mathrm{SRP}$ uptake length.

[b] $U=$ linear uptake rate per unit stream length.

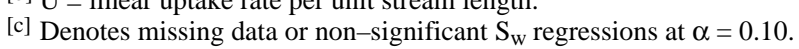

determinant in regulation of seasonal and diel variation in $\mathrm{NO}_{3}-\mathrm{N}$ concentrations in streams (Tate, 1990). Higher winter concentrations may result from slower biotic processes due to decreased temperature. Consequently, it appears that riparian and/or in-stream processes may reduce summer $\mathrm{NO}_{3}-\mathrm{N}$ concentrations in Dry Creek and Cloud Creek, but these processes may not be substantial in Cherokee Creek. With only one winter sampling date, however, results should be interpreted cautiously. Many factors can influence seasonal surface water nutrient concentrations, such as changes in fertilizer and animal waste applications, in-stream disturbances, and effects of hydrology such as karst features. Any one of these factors may have come into play in determining seasonal differences in stream water $\mathrm{NO}_{3}-\mathrm{N}$ concentrations at Cherokee Creek.

Several investigators have shown maintenance of water column P concentrations by benthic sediments (Meyer, 1979; Klotz, 1988; Haggard et al., 1999). In fact, SRP concentrations in the water column of Lake Eucha tributaries have been correlated to the equilibrium phosphate concentration (EPC) of the benthic sediments (Popova, 2000). EPC has been shown to be dominated by physical processes (Klotz, 1988; Baldwin, 1996). However, abiotic or biotic dominance of sediment-P interactions can vary between streams (Haggard et al., 1999; Munn and Meyer, 1990). Therefore, the lack of seasonal difference between SRP concentrations in these streams suggests that regulation of $\mathrm{P}$ maybe via physical processes such as adsorption and desorption.

\section{NUTRIENT RETENTION}

While $\mathrm{P}$ is subject to both abiotic and biotic processes, $\mathrm{NO}_{3}-\mathrm{N}$ retention is driven by biotic uptake or transformation. In 10 of 12 experiments, there was no statistically significant downstream increase or decrease in $\mathrm{NO}_{3}-\mathrm{N}$ concentration after dilution corrections during short-term injections (regression slope not different than zero, $\mathrm{P}>0.10$ ). In the remaining two experiments, $\mathrm{S}_{\mathrm{w}}$ for $\mathrm{NO}_{3}-\mathrm{N}$ $\left(\mathrm{S}_{\mathrm{W}}-\mathrm{NO}_{3}-\mathrm{N}\right)$ was marginally significant in the summer.
Nitrate- $\mathrm{N}$ concentrations increased downstream in Dry Creek on 19 July 1999, possibly from nitrification of mineralized $\mathrm{N}$ in the hyporheic zone (e.g., see Jones et al., 1995). In Cherokee Creek on 3 August $1999, \mathrm{~S}_{\mathrm{w}}-\mathrm{NO}_{3}-\mathrm{N}$ regression was significant but was extremely long (3120 m, $\mathrm{P}=0.06$ ). Overall, $\mathrm{NO}_{3}-\mathrm{N}$ retention was not sufficient to be detected by our methods in these streams. In contrast to these results, several researchers have observed significant $\mathrm{NO}_{3}-\mathrm{N}$ retention in streams throughout the U.S. (e.g., Triska et al., 1989; Munn and Meyer, 1990; Valett et al., 1996). The $\mathrm{S}_{\mathrm{W}}-\mathrm{NO}_{3}-\mathrm{N}$ values in these cases are typically several orders of magnitude less than that observed in Cherokee Creek.

$\mathrm{N}$ limitation in streams within the Ozark Plateau may occur when $\mathrm{NO}_{3}-\mathrm{N}$ concentrations are less than $0.1 \mathrm{mg} \mathrm{L}^{-1}$ (Lohman et al., 1991). However, $\mathrm{NO}_{3}-\mathrm{N}$ was at least five times greater than this concentration in all three study streams, and it is reasonable to assume that biotic demand for $\mathrm{NO}_{3}-\mathrm{N}$ is probably saturated. Therefore, most $\mathrm{NO}_{3}-\mathrm{N}$ is simply transported through the stream ecosystem without any significant removal from the water column by in-stream processes. The magnitude of $\mathrm{NO}_{3}-\mathrm{N}$ concentrations in these streams is not surprising given that the primary agricultural use of pastures is for land application of animal wastes. Soils in this catchment are shallow, and the underlying geology is karstic; thus, nitrification of reduced forms of $\mathrm{N}$ in land-applied animal wastes increases soil solution and groundwater $\mathrm{NO}_{3}-\mathrm{N}$ concentrations (Hubbard and Sheridan, 1989), which in turn may increase stream $\mathrm{NO}_{3}-\mathrm{N}$ concentrations.

Although $\mathrm{NH}_{4}-\mathrm{N}$ concentrations in the water column were below our detection limits $\left(<0.030 \mathrm{mg} \mathrm{L}^{-1}\right)$, it is possible that $\mathrm{NH}_{4}-\mathrm{N}$ adsorbed to benthic sediments can serve as a bio-available $\mathrm{N}$ reserve (Triska et al., 1994). In these streams, sediment-bound $\mathrm{NH}_{4}-\mathrm{N}$ was between 0.8 and $5.2 \mu \mathrm{g} \mathrm{NH}_{4}-\mathrm{N} \mathrm{g}^{-1}$ dry sediment (Popova, 2000). $\mathrm{NH}_{4}-\mathrm{N}$ and $\mathrm{NO}_{3}-\mathrm{N}$ were co-injected in winter during one short-term addition in Cloud Creek and Dry Creek to determine if there was preferential retention of $\mathrm{NH}_{4}-\mathrm{N}$ over $\mathrm{NO}_{3}-\mathrm{N}$ in the study reach. $\mathrm{NH}_{4}-\mathrm{N}$ retention was significant in both streams $\left(\mathrm{S}_{\mathrm{w}}-\mathrm{NH}_{4}-\mathrm{N}=94\right.$ and $200 \mathrm{~m}$ in Cloud Creek and Dry Creek, 
respectively), whereas no significant $\mathrm{NO}_{3}-\mathrm{N}$ retention was observed. The $\mathrm{S}_{\mathrm{w}}-\mathrm{NH}_{4}-\mathrm{N}$ values observed in this study are within the range of values reported for other streams (32 to 900 m; see table 7 in Martí and Sabater, 1996). This evidence indicates that reduced dissolved inorganic $\mathrm{N}$ is significantly retained via abiotic sorption to benthic sediments or preferential biotic uptake, whereas oxidized dissolved inorganic $\mathrm{N}$ is quickly flushed through the stream ecosystem. Thus, these streams are probably not saturated with respect to $\mathrm{NH}_{4}-\mathrm{N}$, as significant retention was observed.

Summer SRP retention was significant $(\alpha=0.05)$ in all streams, with $S_{\mathrm{W}}-\mathrm{SRP}$ ranging from 200 to $900 \mathrm{~m}$ (table 2, fig. 4). These values are comparable to the range of reported values (5 to 697 m; see table 7 in Martí and Sabater, 1996). However, SRP was not efficiently retained during winter injections, as $\mathrm{S}_{\mathrm{W}}-\mathrm{SRP}$ regressions did not reveal significant downstream exponential decreases in concentrations at any site or winter date. This clear seasonal difference was most likely because of reduced biological retention resulting from the temperature decrease, approximately $10^{\circ} \mathrm{C}$. Although seasonal variations in SRP concentrations are probably regulated by physical processes, the longitudinal patterns in short-term $\mathrm{P}$ additions observed in summer likely reflect increased biotic uptake. Furthermore, in our systems, abiotic sorption was not significant during winter, most likely because benthic sediment $\mathrm{P}$ buffering capacity and exchangeable $\mathrm{P}$ were lower in the winter than in the summer and there were few fine sediments (Popova, 2000).

Variations in $S_{\mathrm{w}}$ within or among seasons are often the result of variation in discharge (Butturini and Sabater, 1998), and several investigations have found positive relations between $S_{\mathrm{w}}$ and velocity and/or discharge (see D' Angelo and Webster, 1991; Martí and Sabater, 1996; Valett et al., 1996). Similar to these existing reports, $S_{\mathrm{w}}-\mathrm{SRP}$ was shortest when discharge was lowest at all sites, and it became longer at

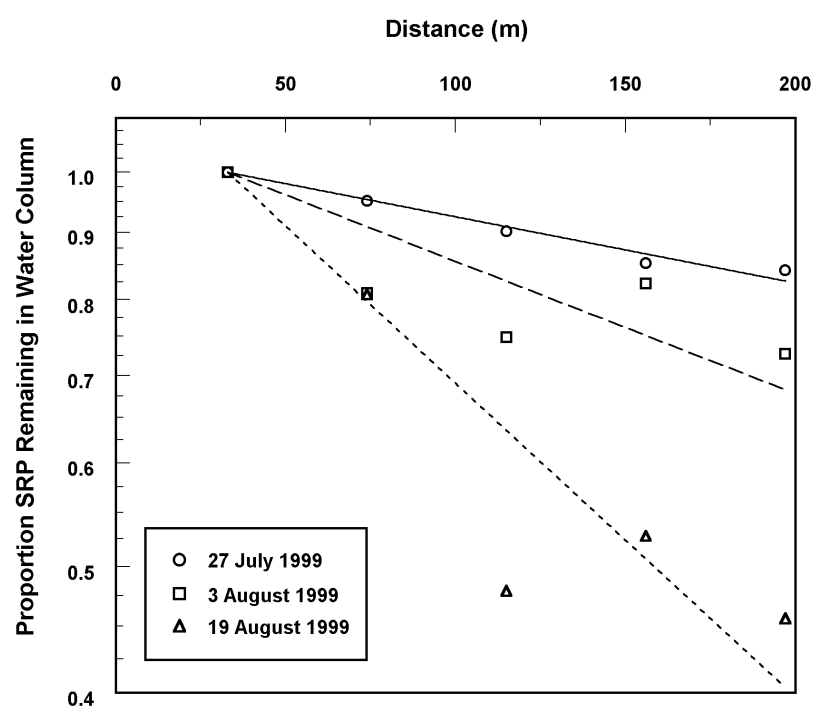

Figure 4. Proportion of SRP remaining in the water column as a function of distance downstream from injection point through summer in Cherokee Creek. Linear regression represents the exponential decline in concentration with distance, from which slope and $S_{w}$ are derived.

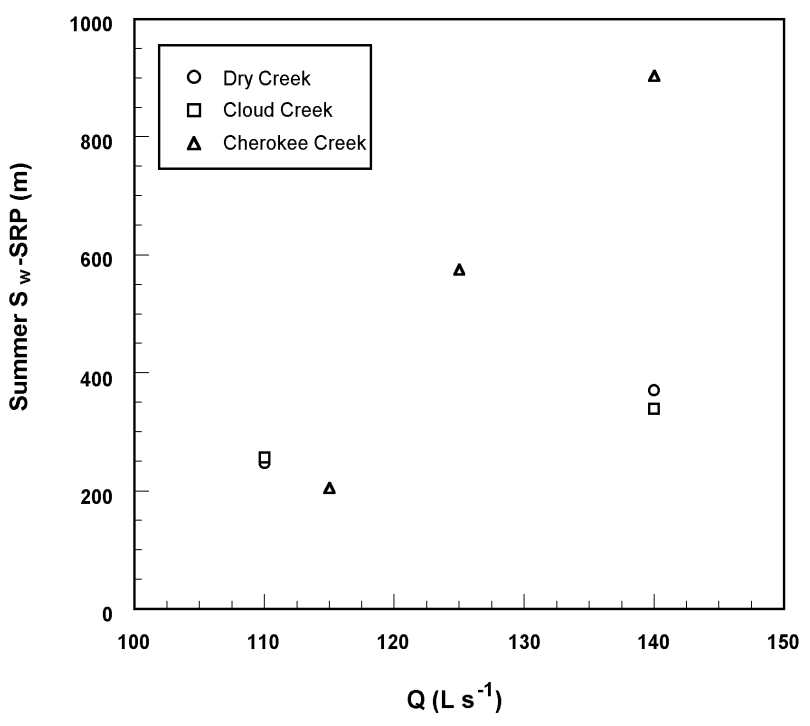

Figure 5. Relationship between summer SRP uptake length and stream flow in Cherokee Creek, Cloud Creek, and Dry Creek.

higher discharges (fig. 5). However, because of the small number of samples $(\mathrm{n}=7)$ and range of discharges $(80-$ $140 \mathrm{~L} \mathrm{~s}^{-1}$ ), this relation was not statistically significant within or among sites $(\mathrm{P}=0.11)$. The ambient SRP uptake rate (U) decreased with increasing median velocity (calculated as median travel time divided by reach length) in these streams (ln transformed, $\mathrm{R}=-0.78, \mathrm{n}=7, \mathrm{P}<0.05$ ) but increased with increasing ambient SRP concentrations (ln transformed, $\mathrm{R}=0.77, \mathrm{n}=7, \mathrm{P}<0.05$ ). At higher velocities, interactions between the water column and benthic sediments and biota decreases, thus the opportunity for $\mathrm{P}$ uptake decreases (Bencala, 1983; Meyer, 1979). Thus, the rate of water transported through aquatic systems is a potentially important determinant in nutrient retention.

\section{Hydrologic Properties}

Transient storage zones are areas of the stream in which the movement of water and nutrients are retarded relative to average water velocity. These areas include backwaters, deep pools, and the hyporheic zone, i.e. deep alluvial sediments where surface water and groundwater often mix. Because water and solutes passing through transient storage zones have increased residence times, they are often important sites for transformation and retention of nutrients in streams. Uptake length has been shown to be inversely correlated with the size of transient storage zones among streams, and differences in the size of these zones can result from differences in geological or geomorphic features of the channel (Valett et al., 1996). Because of the potential importance of transient storage, we estimated the average cross-sectional area of this zone and examined the relationship between transient storage and nutrient retention.

Cherokee Creek was constrained by shallow bedrock underneath benthic substrates and thus, not surprisingly, had the smallest storage cross-sectional area, $\mathrm{A}_{\mathrm{s}}$ (table 3; ln-transformed data, Fisher's LSD, P < 0.05). For within-site trends, the limited number of solute-injections restricted our consideration to Cherokee Creek, where $\mathrm{S}_{\mathrm{w}}-\mathrm{SRP}$ decreased with increasing $\mathrm{A}_{\mathrm{s}}(\mathrm{R}=-0.99, \mathrm{n}=3, \mathrm{P}<0.05)$ (fig. 6). The size of the transient storage zone and discharge (and median 
velocity) were also significantly correlated in Cherokee Creek; therefore, we examined the relationship between $S_{w}$ normalized for median velocity and $\mathrm{A}_{\mathrm{s}}$ among all sampling dates and streams. Our results displayed a significant negative correlation between $A_{s}$ and $S_{w}$ normalized for median velocity $(\mathrm{R}=-0.76, \mathrm{n}=7, \mathrm{P}<0.05)$. Our observations are in general agreement with Valett et al. (1996), who observed an exponential decrease in $\mathrm{S}_{\mathrm{w}}$ with increasing transient storage size. These results suggest that both transient storage and median water velocity are important determinants of SRP retention in these Ozark streams.

\begin{tabular}{|c|c|c|c|c|c|c|}
\hline \multicolumn{7}{|c|}{$\begin{array}{l}\text { Table 3. Hydrologic parameters in Cherokee } \\
\text { Creek, Cloud Creek, and Dry Creek. }\end{array}$} \\
\hline Date & $\begin{array}{c}\mathrm{Q}^{[\mathrm{a}]} \\
\left(\mathrm{L} \mathrm{s}^{-1}\right)\end{array}$ & $\begin{array}{c}\mathrm{A}_{\mathrm{s}} \\
\left(\mathrm{m}^{2}\right)\end{array}$ & $\begin{array}{c}\mathrm{D} \\
\left(\mathrm{s} \mathrm{m}^{-2}\right)\end{array}$ & $\begin{array}{c}\alpha \\
\left(10^{-3} \mathrm{~s}^{-1}\right)\end{array}$ & $\begin{array}{l}\text { Length } \\
(\mathrm{m})\end{array}$ & $\begin{array}{l}\mathrm{T}_{\mathrm{m}} \\
(\mathrm{h})\end{array}$ \\
\hline & \multicolumn{6}{|c|}{ Cherokee Creek } \\
\hline 27 July 99 & 140 & 0.2 & 0.9 & 0.3 & 197 & 0.33 \\
\hline 3 Aug 99 & 125 & 0.5 & 1.3 & 0.2 & 197 & 0.58 \\
\hline 19 Aug 99 & 115 & 0.8 & 0.8 & 0.3 & 197 & 0.70 \\
\hline \multirow[t]{2}{*}{14 Jan 00} & 135 & 0.3 & 0.5 & 0.3 & 197 & 0.41 \\
\hline & \multicolumn{6}{|c|}{ Cloud Creek } \\
\hline 19 July 99 & 140 & 4.6 & 2.0 & 0.4 & 150 & 0.34 \\
\hline 27 July 99 & 110 & 1.4 & 0.8 & 0.2 & 150 & 0.58 \\
\hline 6 Jan 00 & 135 & 3.1 & 1.7 & 0.5 & 150 & 0.27 \\
\hline \multirow[t]{2}{*}{21 Jan 00} & 80 & 0.6 & 0.2 & 0.7 & 150 & 0.67 \\
\hline & \multicolumn{6}{|c|}{ Dry Creek } \\
\hline 19 July 99 & 140 & 1.8 & 7.0 & 0.2 & $201^{[b]}$ & 0.32 \\
\hline 3 Aug 99 & 110 & 3.4 & 0.2 & 0.2 & 159 & 0.42 \\
\hline 6 Jan 00 & 130 & 2.9 & 0.5 & 0.3 & 159 & 0.33 \\
\hline 14 Jan 00 & 85 & 2.7 & 0.4 & 0.2 & 159 & 0.39 \\
\hline
\end{tabular}

[a] $\mathrm{Q}=$ discharge, $\mathrm{A}_{\mathrm{s}}=$ absolute transient storage zone, $\mathrm{D}=$ dispersion coefficient, $\alpha=$ transient storage exchange coefficient, Length = length of study reach from injection point to most downstream sampling site, and $\mathrm{T}_{\mathrm{m}}=$ median travel time or time required to reach one-half of plateau conductivity.

${ }^{[b]}$ Study reach included a pool between injection point and first sampling site. Subsequent injections did not include this feature, but sampling points remained fixed.

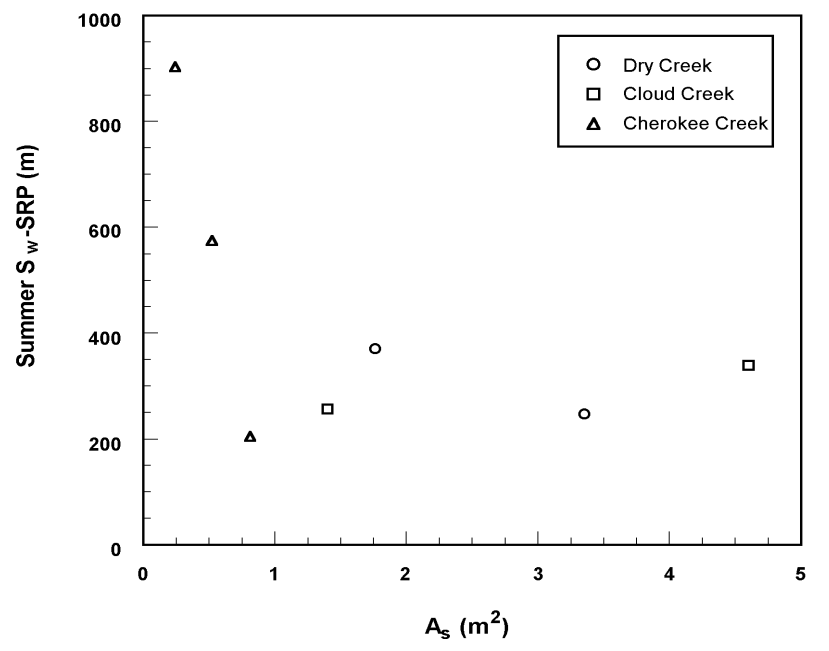

Figure 6. Relationship between summer SRP uptake length and transient storage area in Cherokee Creek, Cloud Creek, and Dry Creek.

\section{Conclusions}

Nutrient retention in streams can be conditioned by catchment characteristics and alterations (Meyer et al., 1988). In these catchments, non-point source pollution from land application of animal wastes is potentially the greatest nutrient contributor to the streams. We expected to observe a gradient between land use and stream nutrient retention efficiency, but it appears that season and stream hydrology (transient storage area and discharge) had the greatest influence on nutrient retention. Unlike absolute SRP concentrations, $S_{\mathrm{w}}-\mathrm{SRP}$ was similar between Cloud Creek and Dry Creek despite the large differences in catchment land use (table 1 and 2). Furthermore, $S_{\mathrm{w}}-\mathrm{SRP}$ was shorter in Cloud Creek compared to Cherokee Creek despite similar proportions of pasture in the upland areas $(63 \%$ and $66 \%$, respectively). These similarities or differences in $\mathrm{S}_{\mathrm{W}}-\mathrm{SRP}$ may reflect variations in the transient storage parameters (table 3). Our results support the findings of Meyer et al. (1999), in which transient storage was more important than the proportion of any one land use category, i.e., agriculture, forest, or urban land, in determining stream nutrient retention. However, if land use changes the hydrologic characteristics of the stream, then $S_{w}$ will be affected (Meyer et al., 1999). In addition, no long-term $S_{\mathrm{w}}$ data (from short-term injections) exists in any catchment that has undergone major land use changes. These data will help substantiate the effects of land use changes on nutrient and hydrologic retention within stream ecosystems.

In conclusion, stream hydrology (discharge and transient storage area) was the most important determinant in regulating nutrient retention within and among streams during the summer season despite large differences in catchment land use between streams. However, the ambient nutrient concentrations in these streams reflected the proportion of agricultural land use (\% pasture) in each catchment. Furthermore, land use changes that alter stream hydrology will impact nutrient retention (Meyer et al., 1999), especially during periods of high biotic activity. Several investigations have shown that alterations in stream hydrology and channel morphology are often associated with a shift in catchment land use from forest to agriculture (Knox, 1977; Jacobson and Primm, 1997). Furthermore, destruction of the riparian zone produces changes in stream morphology and hydrology (Hickin, 1984), along with biological attributes of the system (e.g., see Stauffer et al., 2000), further altering in-stream processes. Thus, catchment-level water quality management should not only consider temporal variations in biological processes and nutrient retention but also the effects of catchment land use on stream hydrology.

\section{ACKNOWLEDGEMENTS}

Funding for this research and manuscript preparation was provided by the Tulsa Metropolitan Utility Authority, a United States Department of Agriculture National Needs Water Sciences Fellowship, and the United States Geological Survey. We thank Harry Chichester from the City of Tulsa, Oklahoma, for assistance in site selection. Special thanks to Jim Schooley and Rob Runkel for reviewing an earlier version of this manuscript, and to four anonymous reviewers for their helpful critiques. 


\section{REFERENCES}

Aumen, N. G., C. P. Hawkins, and S. V. Gregory. 1990. The influence of woody debris on nutrient retention in catastrophically disturbed streams. Hydrobiologia 190: 183-192.

Baldwin, D. S. 1996. Effects of exposure to air and subsequent drying on phosphate sorption characteristics of sediments from a eutrophic reservoir. J Soil Sci. 22: 289-301.

Bencala, K. E. 1983. Simulation of solute transport in a mountain pool-and-riffle stream with a kinetic mass transfer model for sorption. Water Resources Res. 19(3): 732-738.

Butturini, A., and F. Sabater. 1998. Ammonium and phosphate retention in a Mediterranean stream: Hydrologic vs. temperature control. Canadian J. Fish. Aquat. Sci. 55: 1938-1945.

Carpenter, S. R., N. F. Caraco, D. L. Correll, R. W. Howarth, A. N. Sharpley, and V. H. Smith. 1998. Non-point pollution of surface waters with phosphorus and nitrogen. Ecol. Appl. 8(3): 559-568.

City of Tulsa. 2000. Streams of the Lake Eucha-Spavinaw basin. Unpublished data. Tulsa, Oklahoma.

D’Angelo, D. J., and J. R. Webster. 1991. Phosphorus retention in streams draining pine and hardwood catchments in the southern Appalachian mountains. Freshwater Biology 26: 335-345.

Daniel, T. C., A. N. Sharpley, and J. L. Lemunyon. 1998. Agricultural phosphorus and eutrophication: A symposium review. J. Environ. Qual. 27(2): 251-257.

Hart, D. R. 1995. Parameter estimation and stochastic interpretation of the transient storage model for solute transport in streams. Water Resources Res. 31(2): 323-328.

Haggard, B. E. 2000. Stream nutrient retention in the Lake Eucha-Spavinaw Basin. Ph.D. dissertation. Oklahoma State University, Stillwater, Oklahoma.

1997. Trophic status of Beaver Lake, Arkansas. M.S. thesis. University of Arkansas, Fayetteville, Arkansas.

Haggard, B. E., E. H. Stanley, and R. Hyler. 1999.

Sediment-phosphorus relationships in three north-central Oklahoma streams. Trans. ASAE 42(6): 1709-1714.

Hickin, E. J. 1984. Vegetation and river channel dynamics. Canadian Geographer 28(2): 111-126.

Hubbard, R. K., and J. M. Sheridan. 1989. Nitrate movement to groundwater in the southeastern Coastal Plain. J. Soil Water Conserv. 44: 20-27.

Jacobs, T. C., and J. W. Gilliam. 1985. Riparian losses of nitrate from agricultural drainage waters. J. Environ. Qual. 14: $472-478$.

Jacobson, R. B., and A. T. Primm. 1997. Historical land-use changes and potential effects on stream disturbance in the Ozark Plateaus, Missouri. Water-supply paper 2484. Washington, D.C.: U.S. Geological Survey.

Jones, J. B., Jr., S. G. Fisher, and N. B. Grimm. 1995. Nitrification in the hyporheic zone of a desert stream ecosystem. J. N. Am. Benthol. Soc. 14(2): 249-258.

Klotz, R. L. 1988. Sediment control of soluble reactive phosphorus in Hoxie Gorge Creek, New York. Can. J. Fish. Aquat. Sci. 45: 2026-2034.

Knox, H. 1977. Human impacts on Wisconsin stream channels. Ann. Assoc. Amer. Geog. 67: 323-342.

Lohman, K., J. R. Jones, and C. Baysinger-Daniel. 1991. Experimental evidence for nitrogen limitation in a northern Ozark stream. J. N. Am. Benthol. Soc. 10(1): 14-23.

Martí, E., and F. Sabater. 1996. High variability in temporal and spatial nutrient retention in Mediterranean streams. Ecology 77(3): 854-869.

McFarland, A. M. S., and L. M. Hauck. 1999. Relating agricultural land uses to in-stream water quality. J. Environ. Qual. 28: 836-844.
Meyer, J. L. 1979. The role of sediments and bryophytes in phosphorus dynamics: A headwater stream ecosystem. Limnol. Oceanogr. 24(2): 365-376.

Meyer, J. L., and G. E. Likens. 1979. Transport and transformation of phosphorus in a stream ecosystem. Ecology 60: 1255-1269.

Meyer, J. L., M. J. Paul, and W. K. Taulbee. 1999. Nutrient uptake in streams along a gradient of watershed land use. Bull. N. Am. Benthol. Soc. 16(1): 158.

Meyer, J. L., W. H. McDowell, T. L. Bott, J. W. Elwood, C. Ishizaki, J. M. Melack, B. L. Peckarsky, B. J. Peterson, and P. A. Rublee. 1988. Elemental dynamics in streams. J. N. Am. Benthol. Soc. 7(4): 410-432.

Mulholland, P. J., A.D. Steinman, and J. W. Elwood. 1990. Measurement of phosphorus uptake length in streams: Comparisons of radio-tracer and stable $\mathrm{PO}_{4}$ releases. Can. J. Fish. Aquat. Sci. 47: 2351-2357.

Mulholland, P. J., J. D. Newbold, J. W. Elwood, A. Ferren, and J. R. Webster. 1985. Phosphorus spiraling in woodland streams: Seasonal variations. Ecology 66(3): 1012-1023.

Munn, N. L., and J. L. Meyer. 1990. Habitat-specific solute retention in two small streams: An intersite comparison. Ecology 71(6): 2069-2082.

Murphy, J., and J. P. Riley. 1962. A modified single solution method for determination of phosphate in natural waters. Anal. Chim. Acta 27: 31-36.

Newbold, J. D. 1992. Cycles and spirals of nutrients. In The Rivers Handbook 1: 379-408. P. Calow and G. E. Petts, eds. Oxford, U.K.: Blackwell Scientific.

Newbold, J. D., J. W. Elwood, R. V. O'Neill, and A. L. Sheldon. 1983. Phosphorus dynamics in a woodland stream ecosystem: A study of nutrient spiraling. Ecology 64(5): 1249-1265.

Newbold, J. D., J. W. Elwood, R. V. O'Neill, and W. van Winkle. 1981. Measuring nutrient spiraling in streams. Can. J. Fish. Aquat. Sci. 38: 860-863.

Newman, A. 1996. Water pollution from point sources still significant in urban areas. Environ. Sci. Tech. 29: 114.

Oklahoma Conservation Commission. 1997. Clean lakes project: Phase 1. Diagnostic and feasibility study of Lake Eucha. Final report. Oklahoma City, Oklahoma.

Omernik, J. M. 1977. Nonpoint source stream nutrient levels relationships: A nationwide study. 600/3-77-105. Washington, D.C.: U.S. Environmental Protection Agency.

Peterjohn, W. T., and D. L. Correl. 1984. Nutrient dynamics in an agricultural watershed: Observations on the role of a riparian forest. Ecology 65: 1466-1475.

Petersen, J. C. 1992. Trends in stream water quality data in Arkansas during several time periods between 1975 and 1989. Water resources investigation report 92-4044. Washington, D.C.: U.S. Geological Survey.

Petersen, J. C., J. C. Adamski, R. W. Bell, J. V. Davis, S. R. Femmer, D. A. Freiwald, and R. L. Joseph. 1998. Water quality in the Ozark Plateaus, Arkansas, Kansas, Missouri, and Oklahoma, 1992-95. Circular 1158. Washington, D.C.: U.S. Geological Survey.

Popova, Y. A. 2000. Sediment-phosphorus chemistry in Ozark Plateau streams. M.S. thesis. Oklahoma State University, Stillwater, Oklahoma.

Runkel, R. L. 1998. One-dimensional transport with inflow and storage (OTIS): A solute transport model for streams and rivers. Water resources investigation report 98-4018. Washington, D.C.: U.S. Geological Survey.

Sharpley, A. N., S. C. Chapra, R. Wedepohl, T. C. Daniels, and K. R. Reddy. 1994. Managing agricultural phosphorus for the protection of surface water: Issues and options. J. Environ. Qual. 23: 437-51.

Slaughter, M. 2000. Personal communication. Tulsa, Oklahoma.

Stauffer, J. C., R. M. Goldstein, and R. M. Newman. 2000. Relationship of wooded riparian zones and runoff potential to 
fish community composition in agricultural streams. Can. J. Fish. Aquat. Sci. 57: 307-316.

Stream Solute Workshop. 1990. Concepts and methods for assessing solute dynamics in stream ecosystems. J. N. Am. Benthol. Soc. 9(1): 95-119.

Tate, C. M. 1990. Patterns and controls of nitrogen in tallgrass prairie streams. Ecology 71(5): 2007-2018.

Triska, F. J., A. P. Packman, J. H. Duff, and R. J. Avanzino. 1994. Ammonium sorption to channel and riparian sediments: A transient storage pool for dissolved inorganic nitrogen. Biogeochemistry 26: 67-83.

Triska, F. J., V. C. Kennedy, R. J. Avanzino, G. W. Zelweger, and K. E. Bencala. 1989. Retention and transport of nutrients in a third-order stream: channel processes. Ecology 70(6): $1877-1892$.

Valett, H. M., J. A. Morrice, and C. N. Dahn. 1996. Parent lithology, surface-groundwater exchange, and nitrate retention in headwater streams. Limnol. Oceanogr. 41(2): 333-345.

Vitousek, P. M., H. A. Mooney, J. Lubchenco, and J. M. Melillo. 1997. Human domination of the Earth's ecosystems. Science 277: 494-499.

Webster, J. R., and T. P. Ehrman. 1996. Solute dynamics. In Methods in Stream Ecology, 145-160. F. R. Hauer and G. A. Lamberti, eds. San Diego, Calif.: Academic Press, Inc.

Webster, J. R., and B. C. Patten. 1979. Effects of watershed perturbation on stream potassium and calcium dynamics. Ecol. Monogr. 49: 51-72.

Webster, J. R., J. D. D’Angelo, and G. T. Peters. 1991. Nitrate and phosphate uptake in streams at Coweeta Hydrologic Laboratory. Inter. Ver. Theor. Limnol. 24: 1681-1686.

\section{Glossary OF Terms}

Allochthonous Material Organic matter, e.g., leaves, that does not originate in the stream ecosystem but is transported to the stream from outside sources.

Benthos

Catchment

Diel

Hyporheic Zone

\section{Insolation}

Riffle
Biotic assemblages and sediments on stream bottom.

An area that catches water, or more specifically, the drainage area of a reservoir or river.

Periodic alteration of conditions pertaining to a 24 -hour cycle.

Saturated sediments underlying and lateral to a stream or river channel where subsurface and surface waters are actively exchanged.

Solar radiation received over a given area.

A designation of fast moving water in streams, such as a rapid. 
